\title{
Restorative Dental Treatment Approach on an Anorexia Nervosa Patient: A Case Report
}

\author{
Oyun-Erdene Batgerel (Corresponding Author) \\ Health Sciences Institute, Istanbul University, Istanbul, Turkey \\ Faculty of Dentistry, Department of Restorative Dentistry, \\ Istanbul University, Istanbul, Turkey \\ https://orcid.org/0000-0002-1552-2819 \\ E-mail: oyuk1207@yahoo.com \\ Mustafa Alp Boyana \\ Health Sciences Institute, Istanbul University, Istanbul, Turkey \\ Faculty of Dentistry, Department of Restorative Dentistry, \\ Istanbul University, Istanbul, Turkey \\ https://orcid.org/0000-0001-6998-1706 \\ E-mail: alpboyana@gmail.com \\ Emine Kitin \\ Faculty of Dentistry, Department of Restorative Dentistry, \\ Istanbul University, Istanbul, Turkey \\ https://orcid.org/0000-0002-8931-7308 \\ E-mail: dt.eminekitin@hotmail.com \\ Oktay Yazicioglu \\ Faculty of Dentistry, Department of Restorative Dentistry, \\ Istanbul University, Istanbul, Turkey \\ https://orcid.org/0000-0002-6139-802X \\ E-mail: dt.oktay@gmail.com
}

\begin{abstract}
Anorexia nervosa and bulimia nervosa are psychiatric diseases that usually affect women between the ages of 13 and 20, with frequent recurrences of vomiting and disrupt the physiological development process, may even result in death, so early diagnosis and treatment are very important. A multidisciplinary approach is required for the diagnosis, treatment and follow-up of the diseases. In these patients, due to vomiting attacks, tooth erosion, defined as chemical dissolution of tooth tissue without bacteria or loss of substance in non-carious tooth hard tissues, can be seen. Although erosive lesions are usually first seen on the palatal surfaces of the maxillary incisors and first molars, they can adversely affect all hard and soft tissues in the mouth. In this case report, the systemic and dental effects of Anorexia Nervosa and Bulimia Nervosa were discussed and the dental treatment process of a patient diagnosed with Anorexia Nervosa was examined.
\end{abstract}

Keywords: Anorexia nervosa, Bulimia nervosa, erosion, cervical lesion without caries

DOI: $10.7176 / \mathrm{JSTR} / 7-10-05$

\section{Anoreksiya Nervozalı Hastada Restoratif Dental Tedavi Yaklaşımı: Vaka Raporu*}

\author{
*Çalışma, Uluslararası Konservatif Diş Hekimliği Kongresi’nde (ConsEuro, 2019. Berlin, Germany)
} 15.06.2019 tarihinde poster olarak sunulmuştur.

Özet

Anoreksiya nervoza ve bulimia nervoza genellikle 13 ile 20 yaş arasındaki kadınları etkileyen, sık kusma atakları sebebiyle fizyolojik gelişim sürecini bozan ve ölümcül olabilen bu nedenle erken dönem

36 | P a g e

www.iiste.org 
tanı ve tedavileri oldukça önemli olan psikiyatrik hastalıklardır. Bu hastalıkların tanısı, tedavisi ve takibi için multidisipliner bir yaklaşım gereklidir. Hastalarda kusma atakları sebebiyle bakteri olmaksızın diş dokusunun kimyasal olarak çözünmesi ya da çürüksüz diş sert dokularında madde kaybı olarak tanımlanan diş erozyonu görülebilmektedir. Kusma sebebiyle oluşan eroziv lezyonlar genellikle ilk olarak üst kesici ve birinci büyük azı dişlerinin palatinal yüzeylerinde görülse de ağız içinde tüm sert ve yumuşak dokuyu olumsuz etkileyebilmektedir. Bu vaka raporunda Anoreksiya Nervoza ve Bulimia Nervoza'nın sistemik ve dental etkileri ele alınarak Anoreksiya Nervoza teșhisi konulan bir hastanın dental tedavi süreci incelenmiştir.

Anahtar Kelimeler: Anoreksiya Nervoza, Bulimia Nervoza, erozyon, çürüksüz servikal lezyonlar

\section{Giriş}

Anoreksiya Nervoza (AN); kilolu olma korkusu ve sürekli daha zayıf olma isteği sonucunda hastaların yemek yemekten kaçınması ile karakterize psikiyatrik bir hastalıktır. Yeme bozuklukları arasında en sık AN'ye rastlanır[1].

Diğer bir yeme bozukluğu olan Bulimia nervoza (BN) ise "binge" yani tıkanırcasına kontrolsüz yemek yeme, kiloyu kontrol altında tutmak için kendini kusturma veya laksatif kullanımı ile kilo vermeye çalışma ile karakterize bir bozukluktur. BN, AN'ye eşlik eden bir semptom olabileceği gibi normal kilo varlığı ile seyreden farklı bir sendrom olarak da ortaya çıkabilmektedir[1].

Yeme bozuklukları, Diagnostic and Statistical Manual of Mental Disorders'ta (DSM-IV) Anoreksiya Nervoza, Bulimia Nervoza ve Başka Türlü Sınıflandırılamayan Yeme Bozukluğu olarak üç kategoriye ayrılmaktadır.

\subsection{Yeme Bozukluklart}

\subsubsection{Anoreksiya Nervoza}

AN; 1873 yllında Gull ve Laseque tarafindan tanımlanmıştır[2]. Hastalık semptomları; kilo kaybı için üstün çaba gösterme, kilo almaktan çok fazla korkma, hormonal bozukluklar, cinsel işlev bozukluğu, kadınlarda amenore varlı̆ğ, sürekli kilo verme ve oldukça zayıf olma isteği olarak belirlenmiştir. Hastaların vücut kitle indexi $17.5 \mathrm{~kg} / \mathrm{m}^{2}$ 'nin altındadır ve hastalar genellikle ince ve kaşektik görünümdedirler[2,3].

AN'li hastalarda kendine güven eksikliği, uykusuzluk, kesin bir 'ya hep ya hiç' tarzı düşünce biçimi, duygu durum bozuklukları, agresif davranışlar, içe kapanıklık, karşı cinsle iletişim bozukluğu gibi bulgular da görülebilmektedir[4]. Hastalardaki zayıf olma isteği, hastaların kendi arzusu olduğu için genellikle hastalar tedavi arayışına girmemektedirler[5]. Klinik olarak vital bulgularında hipotansiyon ve hipotermi seyredebilmektedir. Parmak derisinde kendini kusturma alışkanlığına bağlı olarak kalınlaşma ve sertleşme, ciltte ve saç diplerinde kuruluk, cilt dokusunda lanugo tüyleri görülebilmektedir Kalpte bradikardi ve mitral kapak prolapsusu izlenebilmektedir[6]. Bu klinik belirtilere ek olarak diş sert dokularında çürük ve erozyon lezyonları da gözlenebilmektedir. Dental erozyon vakalarında mine lezyonları erken dönemde diş dokusunda yumuşama, renk değişikliği ya da ağrı hissi şeklinde görülmemektedir. Lezyonlar yeni başladığı dönemde portakal kabuğu görünümündedir ve lezyon fark edilememektedir. Lezyon mine tabakasından dentin tabakasına doğru ilerledikçe dentin dokusunun sarı rengi yansımaya başlar, $U$ ya da disk şeklinde bir kavite oluşumu gözlenebilmektedir. Lezyon ilerledikçe dentinde sklerotik yapı gözlenebilmekte ve daha da ilerleyen vakalarda pulpanın açığa çıkması söz konusu olabilmektedir[7]. Mine yüzeyi abrazyon varlığında parlak, aktif erozyon varlı̆̆ında ise mat görünmektedir. Dental erozyon dişin tüm yüzeylerinde meydana gelebilmektedir. Lezyonlar çoğu zaman üst çene ön bölge dişlerin palatinal ve alt birinci büyük azı dişlerinin oklüzal yüzeylerinde gözlenebilmektedir. Ağızdaki restorasyonların çevredeki diş dokusuna göre şapka gibi yükselmiş şekilde bir görüntü oluşturması erozyonun tipik bulgularından olduğu bildirilmiştir[8-10]. Hastalarda bu belirtilere ek olarak uzun süreli açlık sebebiyle hiposalivasyona bağlı olarak kserostomi görülebilmektedir[11].

\subsubsection{Bulimia Nervoza}

BN olan hastalarda aşırı yemek yeme davranışı olmasına rağmen kısıtlı kilo alımı gözlenmektedir[12]. $\mathrm{Bu}$ dönemde hastanın tükettiği kalori miktarı yirmi binli rakamlara kadar çıkabilmektedir. Nöbet esnasında hastalar şuurlarını kaybederek aşırı yeme davranışında bulunduklarını belirtmektedirler. Yeme nöbetlerinin sıklı̆̆ı günde birkaç defa olabileceği gibi haftada bir de görülebilmektedir.

37 I P a g e

www.iiste.org 
Toplumda görülme insidansı \%1 olarak bildirilmiştir[4]. BN'nin kadınlarda görülme sıklığı erkeklere oranla 10 kat daha fazladır ve BN olan erkeklerin çoğunluğunda cinsel kimlik problemi ve cinsel sorunlar gözlenmektedir[4].

BN'de ayırıcı tanı ölçütleri, tekrar eden tıkanırcasına yemek yeme nöbetlerinin olması, normal bir insanın belli sürede yiyebileceğinden çok daha fazla miktarda yemeği bir anda tüketme, kilo alımını engellemek için aşırı egzersiz yapma, kendi kendini kusturma, diüretik, laksatif ya da lavman kullanımı gibi davranışları tekrarlama, vücut biçimi ve kilo değeriyle ilgili obsesyona sahip olma olarak sıralanmıştır[11].

BN'li hastalar genellikle normal kiloda görülmektedir. Hastaların tükürük bezlerindeki büyümeden dolayı yanaklarında şişkin bir görünüm olmasına karşın, beden zayıf görünmektedir. Kusmaya bağlı olarak ağız içerisinde çürükler ve eroziv diş lezyonları görülebilmektedir[6].

\subsubsection{Başka Türlü Adlandırlamayan Yeme Bozukluğu}

AN ve BN'deki tanı ölçütlerini karşılamayan, tıkanırcasına yeme episodlarının bulunduğu yeme bozuklukları olarak sinıflandırılmaktadır.

\subsection{Dental Tedavi Seçenekleri}

Yeme bozukluğu olan hastalarda tedavi basamakları acil tedavi, koruyucu tedavi, restoratif tedavi ve protetik tedavi olmak üzere dört bölümde değerlendirilebilir.

\subsubsection{Acil Tedavi}

Hastalar diş kliniğine genellikle acil bir durumun tedavisi için başvururlar. En sık rastlanılan şikâyet dentin dokusu ya da pulpa dokusunun açığa çıkması sebebiyle hissedilen dental hassasiyettir. Florür içeren ajanlar, potasyum, kalsiyum, arjinin içeren ajanlar, oksalat ve stronsiyum tuzları gibi desensitize edici ajanlar ve adeziv sistemler hassasiyet tedavisinde kullanılabilir[13]. Gelişen lazer teknolojisi, dentin hassasiyetinin tedavisinde geleneksel yöntemlere çağdaş bir alternatif sunmaktadır. Dentin hassasiyetinin tedavisinde düşük seviyeli lazer kullanımı ile ilgili literatürde pozitif klinik sonuçlara rastlanmaktadır[14,15]. Düşük seviyeli lazer dışında, yüksek seviyeli lazer tedavisi de dentin hipersensitivitesi için kullanılabilmektedir[16]. Dentin aşırı duyarlllığının tedavisi için Nd:YAG lazerler daha çok tercih edilse de, CO2 lazer, Er:YAG lazer ve son zamanlarda Er,Cr:YSGG lazer gibi diğer lazer ekipmanlarının da kullanılabileceği bildirilmektedir[17].

\subsubsection{Koruyucu Tedavi}

Acil tedaviyi takiben yeme bozukluğu bulunan hastalarda koruyucu tedaviler uygulamak diş hekiminin ana amaçlarından biri olmalıdır. Koruyucu tedaviye hemen başlanmalıdır çünkü diş sert dokularında oluşan erozyonunun geri dönüşü yoktur ve ilerlediğinde restoratif tedaviye gerek duyulmaktadır. Koruyucu tedavide esas amaç daha fazla yıkım oluşumunu önlemektir[18].

Koruyucu tedavi programının ilk basamağı hasta eğitimidir. Kserostomi'ye neden olabilecek ilaç kullanan hastaların yapay tükürük kullanması sağlanmalıdır. Yemeklerden sonra şekersiz sakız çiğnenmesi remineralizasyonu desteklediği ve çürük oluşumunu önleyici olarak tükürük akışını arttırdığı bildirilmiştir[19]. Karyojenik ve asidik yiyeceklerin az tüketilmesi önerilirken, çürük oluşumunda beslenmenin önemi vurgulanmalıdır[18]. Kamak ve ark. asit içeren yiyecek ve içecek tüketiminin ardından 30 dakika içerisinde diş firçalanmasının erozyon riskini arttırdığını belirtmişlerdir[20]. Körner ve ark. diş sert dokularının kalsiyum iyonları ile sature olduğu durumlarda eroziv etkilerin daha az ortaya çıkmasına dayanarak, kusma öncesinde kalsiyum içerikli ağız gargaralarının kullanılmasının diş sert dokularındaki erozyonu azaltabileceğini vurgulamışlardır[21]. Normal şartlarda tükürüğün $\mathrm{pH}$ değeri 6,2 ile 7,6 arasında değişmektedir. Milosevic ve ark. tarafindan kusma sonrası ağız içi $\mathrm{pH}$ değeri 2.9 - 5.0 (ortalama 3.8) olarak bildirilmiştir[22]. Bu değerin, mine için kritik pH'ın altında olduğu unutulmamalıdır.

Hastaya özel hazırlanan plastik splintlerin kusma atakları sırasında kullanımı ve splint içerisine suda çözünmüş sodyum bikarbonat solüsyonu, sodyum floridli solüsyonlar konulmasının da mine çözünmesine karşı koruyucu olduğu bildirilmiş, kusma sonrası oluşan asidi nötralize etmek için \% $0.5^{\prime}$ lik sodyum florid içeren gargaraların kullanımı önerilmiştir[18]. 


\subsubsection{Restoratif Tedavi}

Mevcut ağız içi durumu stabilize etmek için başlangıçta geçici bir tedavi uygulanması önerilir. Çünkü iyi bir prognoz için hastanın aşırı yeme ve kusma ataklarının sonlanması gerekmektedir. Hasta psikolojik olarak stabil hale geldiğinde kalıcı restoratif işlemlere başlanılabilir[23].

Restoratif tedavi planının kapsamı; hastanın belirttiği şikayetler ile lezyonların derinliğine, şiddetine ve boyutuna bağlıdır. Restorasyon gerektiren dişlerde diş hassasiyetinin giderilmesi ve dental erozyonun önlenmesi için kompozit reçineler ve flor salınımı yapan cam iyonomer simanlar tercih edilebilir.

\subsubsection{Protetik Tedavi}

Anterior dişlerde mine kaybı mevcutsa ve estetik problem oluşturuyorsa daha az preparasyon gerektirdiğinden reçine siman ile yapıştırılan porselen lamina veneerlerin yapımı gerekebilir[24].

Vertikal dikey boyut kaybıyla sonuçlanan daha şiddetli vakalarda oklüzal rehabilitasyon için tüm ağzı kapsayan protetik işlemler ya da overley uygulamaları uygun çözüm olabilir[25].

Shuyler ve ark. tarafindan tanımlanan vertikal boyut kaybına bağlı tedavi seçeneklerine göre ise $2 \mathrm{~mm}$ 'den az doku kaybında direkt kompozit restorasyonlar önerilirken, $2 \mathrm{~mm}$ 'yi aşan doku kaybında ise indirekt seramik veneer ve overley uygulamaları önerilmektedir. Erozyon sebebiyle 4mm'den fazla doku kaybı mevcutsa indirekt seramik kuron restorasyonlar tavsiye edilmektedir[26].

\section{Olgu}

28 yaşında, bekar, üniversite mezunu, İtalya'da ikamet etmekte olan D.Ö. isimli kadın hasta İstanbul Üniversitesi Diş Hekimliği Fakültesine diş tedavileri için müracaat etmiştir. Hastanın mevcut sistemik hastalıkları ile ilgili tedavi geçmişine bakıldığında;

2001 yılında 10 yaşındayken gaitada parazit bulgusu nedeni ile 3 ay içinde 38 kilodan 30 kiloya düşmüş ve bu sorunlar nedeni ile Samsun Ondokuz Mayıs Üniversitesi Tıp Fakültesi Endokrinoloji bölümünde 20 gün tedavi görmüştür.

Hasta psikiyatrik olarak 2003 yılında Samsun Ondokuz Mayıs Üniversitesi Tip Fakültesi Psikiyatri kliniğinde 4 ay tedavi görmüş ve bu sürede kendisine AN tanısı konulmuştur. 2005 yılında Bursa Uludağ Üniversitesi Psikiyatri kliniğinde 6 ay, 2012 yılında da İstanbul Üniversitesi Çapa Tıp Fakültesi Psikiyatri kliniğinde 4 ay tekrar AN tedavisi gördüğ̈nü belirtmiştir. Taburcu olduktan sonra İtalya'da yaşamaya devam ederken çeşitli maddi sorunlarından dolayı depresyon şikayeti sebebiyle düzenli kontrollerine devam etmiş fakat son dönemde yeme ve kusma nöbetlerinde artış olmuştur. Hasta; kilo almaktan kaçınması, haftada 2-3 kez gizli olarak spor yapması ve 36 kilodan 30 kiloya düşmesi sebebiyle 2019 yılında (yaş=28) tekrar İstanbul Üniversitesi Çapa Tıp fakültesinde Psikiyatri bölümüne başvurmuş ve tedavi görmeye başlamıştır. Aynı zaman içerisinde hasta, AN kaynaklı oluşan dental erozyon sonucunda meydana gelen estetik ve fonksiyonel problemleri sebebiyle İstanbul Üniversitesi Diş Hekimliği Fakültesi Restoratif Diş Tedavisi Anabilim Dalı Yılmaz Manisalı Kliniği’ne başvurmuştur.

Yapılan radyografik (Resim 1) ve ağız içi muayene (Resim 2A1-A2) sonucunda dental erozyondan kaynaklanan estetik ve fonksiyonel problemler tespit edilmiştir. Ağız içi muayene bulgularına baktığımızda, üst ve alt çenede hem anterior hem de posterior dişlerin özellikle bukkal yüzeylerinin servikal bölgelerinde meydana gelmiş eroziv alanlar göze çarpmıştır. Ayrıca üst çene anterior dişlerin palatinal yüzeylerinde de mine dokusu kaybına bağlı olarak dentin dokusunun renginin daha net şekilde yansıdığı erozyon lezyonları görülmüştür. Hastanın yaşı ve psikolojik durumu göz önüne alınarak konservatif bir yaklaşımla direkt kompozit reçine restorasyon uygulanmasına karar verilmiştir. Diş renginin belirlenmesini takiben anterior ve posterior dişlerin yüzeyindeki plak retansiyonu düşük devirli döner enstrümana takılan polisaj firçası yardımıyla ortadan kaldırılmıştır. Lokal anestezi uygulamasının ardından retraksiyon ipleri yerleştirilmiştir. Diş yüzeyi \%35'lik fosforik asit (Scotchbond Asit, 3M ESPE, St. Paul, MN, USA) ile demineralize edilerek hava-su spreyi ile yıkanıp kurutulmuştur. Üretici firmanın önerdiği doğrultuda restore edilecek diş yüzeyine 20 saniye boyunca adeziv (Scotchbond Universal Bond; 3M ESPE, St. Paul, MN, USA) uygulanmıştır. Adeziv, LED ışık cihazı (3M ESPE Elipar S10, dalga boyu:430-480 nm, ş̧ı yoğunluğu: $1200 \mathrm{Mw} / \mathrm{cm} 2$ ) ile polimerize edilmiştir. Estetiğin sağlanabilmesi için nanohibrit içerikli kompozit reçine (Filtek ${ }^{\mathrm{TM}}$ Z550, 3M ESPE, St. Paul, MN, USA) ile yine aynı polimerizasyon cihazı kullanılarak restorasyonlar tamamlanmıştır. Restorasyonların oklüzyon kontrolü için artikülasyon kağıdı (Bausch Inc., Nashua, USA) ile hastanın fonksiyonel hareketleri kontrol edilmiştir ve ince grenli elmas frez ile gerekli düzenlemeler yapılmıştır. Son olarak Sof-lex cila diskleri (Sof-Lex, 3M ESPE, St.Paul, MN, USA) kullanma talimatına uygun olacak şekilde sırasıyla uygulanarak ve kompozit bitirme lastikleri (Flexi-Snap KIT, Edenta, İsviçre)

39 | P a g e

www.iiste.org 
seri olarak kullanılarak bitim ve cila işlemleri tamamlanmıştır. (Resim 3, B1-B2) 6. ayda kontrole çağrılan hastanın ağız içi muayenesi yapılmıştır. (Resim 4, C1-C2)

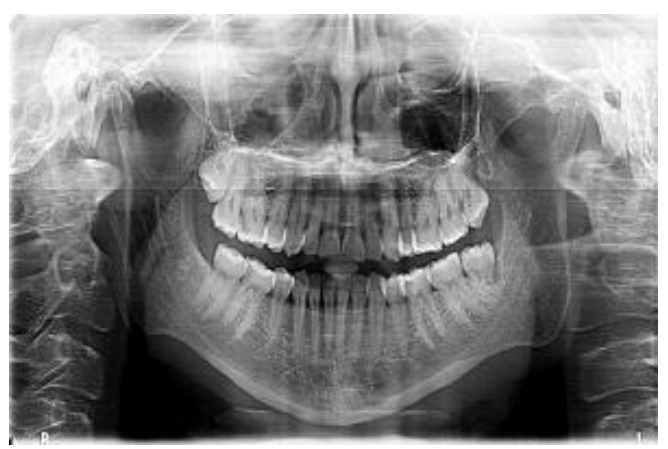

Resim 1. Panaromik röntgen görüntüsü

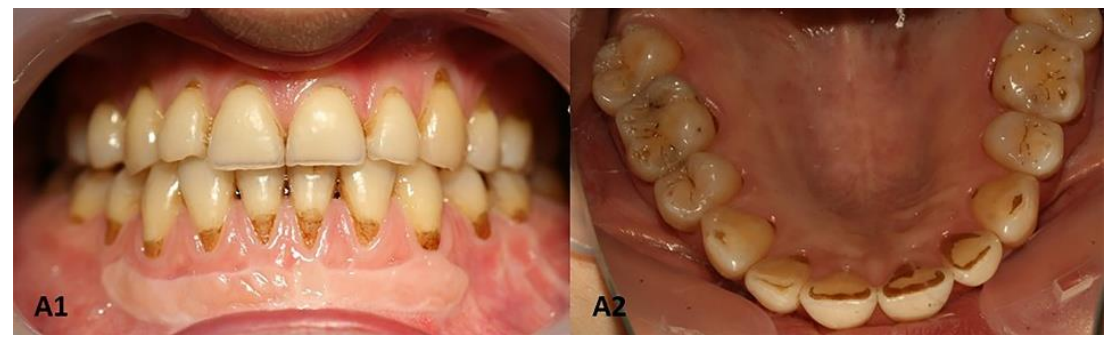

Resim 2. (A1) Üst ve alt çenedeki dişlerin bukkal yüzeylerindeki servikal bölgelerde oluşan yaygın eroziv lezyonlar. (A2) Üst çenedeki dişlerin palatinal yüzeylerinde oluşan yaygın eroziv lezyonlar

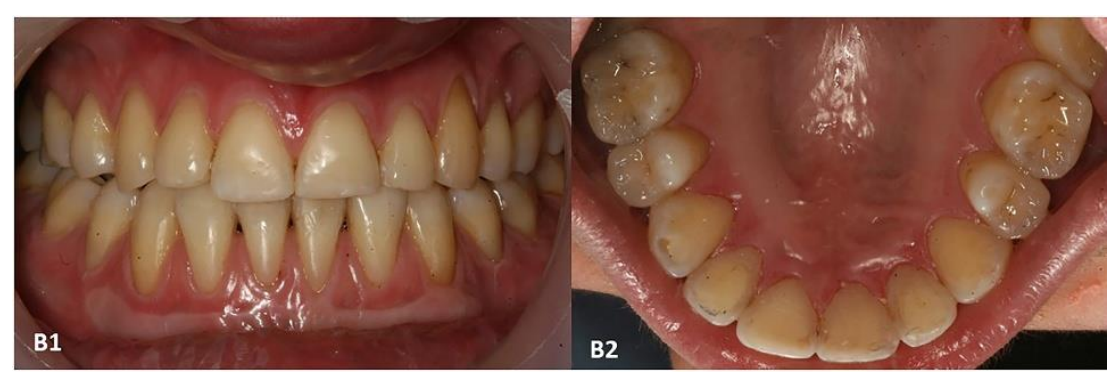

Resim 3. (B1) Üst ve alt çenedeki dişlerin bukkal yüzeylerindeki eroziv lezyonların direkt kompozit restorasyonlar ile tamamlanmış görüntüsü. (B2) Üst çenedeki dişlerin palatinal yüzeylerinde oluşan yaygın eroziv lezyonların direkt kompozit restorasyonlar ile tamamlanmış görüntüsü.

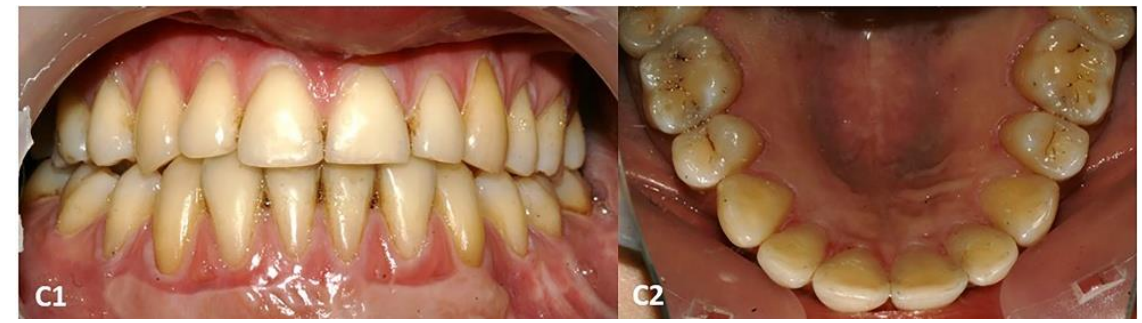

Resim 4. (C1) Üst ve alt çenedeki dişlerin bukkal yüzeylerinin 6. ay kontrol görüntüsü (C2) Üst çenedeki dişlerin palatinal yüzeylerinin 6 . ay kontrol görüntüsü

\section{Tartışma}

Genç erişkinlerde AN görülme sıklığı \%4’tür. En sık görüldüğü yaş aralığ1 15-19'dur. Hastalık özellikle ergenlik çağının başında ve ortalarında relaps ve remisyonlar gösterir. İntihar oranı tüm hastalar 
içerisinde \%2-5 olarak bildirilmiştir[4]. Hastaların altta yatan sistemik hastalıklar ve biyolojik komplikasyonlar sebebiyle ölüm oranı ise \%6-9'dur[4].

BN olan vakalara baktığımız zaman hastalar, başlangıcından seneler sonra tedavi arayıșına girerler. Genellikle hızlı bir şekilde iyileşme beklentileri vardır. İleri yaştaki hastalarda antidepresanların, özellikle fluoksetin grubu ilaçların fayda sağladığını gösteren çalışmalar mevcuttur[27]. Tedavi planı oluşturulurken her bir bulgu tek tek kapsamlı şekilde incelenmelidir. Kognitif davranış̧̧ı terapi ile psikoeğitimsel terapiden hastaların \%30'u fayda görmektedir fakat kişilik bozukluğu bulunan vakalarda uzun süreli ve destekleyici tedavi yaklaşımları önemlidir[4].

AN ve BN'li hastalarda genel tedavi prosedürü olarak amaç yalnız kilo alımını desteklemek üzerine olmamalıdır. Hastanın kilo alımı desteklenirken aynı zamanda psikolojik tedavisi sağlanmalıdır ve hastalığın tekrar nüksetmesi engellenmelidir[28]. Tedavide aile terapisi ve bireysel psikolojik terapinin faydası büyüktür. Aynı zamanda depresyon bulguları varsa psikiyatrik ilaçlar tedaviye eklenmelidir[28].

Kliniğimize başvuran D.Ö. isimli hastadan alınan detaylı anamnez sonucunda hastanın geçmişte başlayan ve devam eden AN ve buna eşlik eden BN için tedavi gördüğü, 18 yıldır hastanın farklı kuruluşların Psikiyatri servislerine tedavi için müracaat ettiği ve psikiyatrik tedavisinin günümüzde hala devam ettiği ögrrenildi. Detaylı dental anamnez sonucu dişlerde AN ve BN kaynaklı dental aktif erozyon olduğu tespit edildi.

Anterior dişlerdeki AN ve BN kaynaklı eroziv çürüksüz servikal lezyonların meydana getirdiği renk ve şekil bozuklukları hastada estetik ve psikolojik açıdan büyük problem oluşturmaktadır. Bäckman B. ve Holm AK. yaptıkları çalışmada benzer şekilde BN kaynaklı eroziv lezyonların hastalarda estetik sorunlar çıkardığını bildirmiş aynı zamanda estetik kaybının hastaların psikolojisini de negatif yönde etkilediğini bildirmişlerdir[29]. Anterior dişlerdeki problemleri gidermek için estetik restorasyonlar olarak; reçine esaslı kompozitler, direkt ve indirekt kompozit lamina, porselen lamina, metal destekli ve zirkonyum destekli porselen kaplama, paslanmayan çelik kuron gibi restorasyonlar uygulanmaktadır[30,31]. Günümüz diş hekimliğinde minimal invaziv yaklaşım tekniği, restorasyon seçeneklerinde daha konservatif bir yaklaşımı beraberinde getirmektedir[32]. Reçine kompozit restorasyonlar, minimal invaziv yaklaşım ile uygulayabileceğimiz en iyi tedavi seçeneklerindendir[3234]. Hastanın estetik beklentisi minimal diş preparasyonu ile çoğu durumda anestezi dahi gerektirmeden kısa sürede ve kolaylıkla karşılanmaktadır[32]. Hastamızdaki eroziv lezyonlar her ne kadar pulpa dokusuna kadar ulaşmayıp dentin düzeyinde seyretse de hastanın dentin hassasiyetinin fazla olması sebebi ve hasta-hekim psikolojisinin yapılan işlemler sırasında negatif etkilenmemesi için tedavilerinin lokal anestezi altında tamamlanmasına dikkat edilmiştir.

Pantons-Melo ve ark. anterior bölgede estetiği sağlamak için kesici dişlerde direkt kompozit restorasyon uyguladıkları çalışmada, direkt tekniğin indirekt tekniğe göre oldukça hızlı ve daha ekonomik bir teknik olduğundan bahsetmişlerdir[35].

Devoto ve ark.'nın vaka çalışmasına baktığımızda direkt adeziv sistemlerin hem ekonomik açıdan hasta ve hekim için avantajlı olduğunu hem de biyolojik olarak daha fazla dokunun korunmasına olanak sağladığını söylemişlerdir[36].

Restorasyon tamirinin kolay olması, kompozit reçine restorasyonlar için önemli bir avantajdır. Kanzov ve ark. restorasyon tamiri ile ilgili yaptıkları meta analiz çalışmasında; kompozit restorasyonlarda meydana gelen deformitelerde tüm restorasyonu değiştirmek yerine uygulanacak tamir işleminin restorasyonun total ağızda kalım süresini uzattığını, daha az tedavi süresine ihtiyaç duyulduğunu, daha az maliyet oluşturduğunu, hasta tarafindan daha iyi tolere edildiğini ve oluşabilecek komplikasyon risklerinin daha az olacağını belirtmişlerdir[37]. Bu bilgiler doğrultusunda hekim uygulayacağı restorasyon tipini seçerken, hastanın isteklerini göz önünde bulundurmalı ve kendi mesleki bilgilerini kullanarak en uygun tedavi seçeneğini belirlemelidir. Yazıcıoğlu O. çivi diş şeklindeki yan keser dişlerin restorasyonunda tedavi yaklaşımları konulu çalışmasında, dişlerin estetik olarak düzeltilmesinde interdisipliner planlama, hekimin tecrübe ve yetenekleri ile birleştirilince en iyi sonucun alınacağını bildirmiştir[38]. Başka bir vaka raporunda talon tüberkülü bulunan santral dişte estetik rehabilitasyonu sağlamak için direkt kompozit reçine restorasyon kullanılmıştır. Tercih etme sebebi olarak; hastanın tedavi ünitinde geçirdiği sürenin az olması, düşük maliyet, yüksek biyokompatibilite ve minimal sert doku kaybının olduğunu belirtmiştir[39]. Tüm bu bilgiler ışığında biz de D.Ö. isimli hastamızın erozyon sebebiyle açığa çıkmış dentin dokusu ve açıkta kalan dentin tübüllerinden kaynaklanan hassasiyet şikayetini gidermek, kaybolan estetik ve fonksiyonu tekrar kazandırmak amacıyla tedavisinde minimal invaziv yaklaşımla direkt kompozit reçine restorasyonlar yapmayı tercih ettik.

41 I P a g e

www.iiste.org 
AN ve BN'li hastalar, hastalığın erken dönemlerinde problemin varlığını reddetme eğilimindedirler. Diş hekimleri, dental dokularda meydana gelen değişimleri fark ederek yeme bozukluğunun hastalarda oluşturduğu sağlık sorunlarını ilk gözlemleyen kişi olabilir[40]. Bu sebeple diş hekimlerinin hastalığı doğru şekilde teşhis edebilmeleri için yeme bozukluklarının oral dokular üzerindeki etkileri hakkında detaylı bilgi sahibi olması gerekmektedir. Hastalığın altında yatan psikolojik problemleri tedavi etmek diş hekiminin görevi olmasa da bu konuda hastayı tedavi olmak için cesaretlendirmek hayati bir meseledir. Ayrıca hastanın kendini rahat ifade edebilmesi için güvenilir bir ortam sağlamak da diş hekiminin görevidir[41]. Küey G.A. ve ark. yeme bozukluğu olan hastalarda yaptığı çalışmada sorunun sadece beden algısındaki bozukluğa indirgenmemesi gerektiğini ve daha detaylı anamnez alınması gerektiğini vurgulamıştır[42]. Anamnez alınırken hastanın dental hikayesi, yaşam stili, beslenme alışkanlıkları, ağız hijyen durumu, tükürük akış hızı, diş sert ve yumuşak dokularının mevcut durumu dikkatli şekilde değerlendirilmelidir[43]. Hastamız D.Ö.'nün beyanına göre kendisi yaşadığı maddi ve manevi kaygılar ile stresli yaşam koşulları sebebiyle depresyona girdiğini ve bununla ilgili tedavi gördüğünü belirtmiştir. Yukarıda açıklanan bilgiler ve hastamızın durumuyla birlikte yeme bozukluğu ile psikolojik problemlerin oldukça ilişkili olgular olduğunu söyleyebiliriz.

Järvinen VK ve ark. haftada bir kusan bireylerde dental erozyon riskinin 4 kat, kronik olarak sürekli kusan bireylerde ise 18 kat daha fazla olduğunu vurgulamışlardır[10]. İçsel faktörlerden kaynaklanan erozyonlar çoğunlukla üst çenede kesici dişlerin palatinal yüzeylerini etkilemektedir[10]. Benzer şekilde hastamız D.Ö.'de de üst çene kesici dişlerin palatinal yüzeylerinde lezyonlar gözlenmiştir. Erozyon lezyonları sınırları mine ya da dentin dokusunda sonlanabileceği gibi bazı durumlarda pulpaya kadar ulaşabilmektedir[44,45]. de Moor'un vaka raporunda, 20 yaşındaki kadın hastanın üst çene ön bölge dişlerinin bukkal ve palatinal yüzeylerinde dental erozyon olduğu belirtilmiş ve hassasiyet şikayetinin giderilmesi, kaybolan dokunun onarılması için uygulanabilecek tedavi seçenekleri hastaya sunulmuştur Madde kaybının bukkal bölgede sadece servikale yakın bölgelerde olması dolayısıyla lamina veneer tedavi seçenekleri arasında değerlendirilmiş fakat ilk tercih olarak düşünülmemiştir. Eroziv alanların hem bukkal hem de palatinal yüzeyde gözlenmesi tam kuron kaplama ile tedavi seçeneğini akla getirse de var olan sağlam dokunun korunması için defektlerin konservatif tedavi yaklaşımı ile direkt kompozit reçine restorasyonlar uygulanarak onarılmasına karar verilmiştir ve bizim çalışmamızla benzer şekilde dişler direkt kompozit reçine restorasyon ile tedavi edilmiştir. Tedavi sonrası hastaya her gün nötral florid içeren gargara ile ağzını çalkalaması ve yüksek florür konsantrasyonu içeren jel (Elmex Gelee) ile dişlerini firçalaması tavsiye edilmiştir. Ayrıca asit ataklarını önlemek amacıyla meyve suyu ve asitli içecekleri tüketmemesi tavsiye edilmiştir. Kontrol randevularının önemi vurgulanmış ve hasta 6 aylık düzenli periyotlarla kontrole çağrılmıştır[46].

Hemming ile Poyser, dental erozyon ile ilgili çalışmalarında, direkt kompozit reçine restorasyonların uygun erozyon vakalarında klinik performanslarının kabul edilebilir düzeyde olduğunu vurgulamışlardır[47,48]. Kaur ve ark. çalışmalarında mine dokusunun kompozit ve reçine modifiye cam iyonomer materyaline oranla firçalama ve asit abrazyonuna karşı daha hassas olduğunu ve mine dokusunda daha fazla abrazyon meydana geldiğini kanıtlamışlardır[49]. Zafersoy ve ark. erozyon, abrazyon, abfraksiyon ve atrizyon lezyonlarının tek başına oluşabileceği gibi tek diş üzerinde lezyonların birlikte de gözlemlenebileceğini bildirmiştir[5]. Her ne kadar bizim vakamızda abrazyon, abfraksiyon gözlenmese de anterior ve posterior dişlerin vestibül ve palatinal yüzeylerinde görülen eroziv lezyonlara, posterior dişlerin oklüzal yüzeyleri ve anterior dişlerin insizal kenarları da eşlik etmektedir. Erozyon ile birlikte atrizyon lezyonların varlığı da Zafersoy ve ark.'nın gözlemlerini destekler niteliktedir.

Harrison'a göre; AN olup iyileşen hastaların 2/3'ünde 18 ay sonrasında hastalık tekrar nüksedebilir ve altta yatan etiyolojik problemin çözülmemiş olması oral problemlerin tekrar ortaya çıkmasına ya da geleneksel tedavi yöntemlerinin başarısız olmasına sebep olabilir[50].Bu sebeple bu tür hastalarda uygulanacak tedavi kadar yapılan tedavinin kontrolü de oldukça önemlidir. Hastamıza özellikle ilk 3 yıl boyunca her 6 ayda bir kontrole gelmesi tavsiye edilmiştir fakat 6 . Aydaki ilk kontrol randevusu sonrasında hasta yurt dışında ikamet etmesi sebebiyle düzenlenen diğer kontrol randevularına gelmemiş ve takip seansları yapılamamıştır. Bu nedenle 6 ay sonrasında hasta ile kurulan iş birliği ve takibin devam etmemesi sonucu hastaya uyguladığımız dental tedavinin başarısı ve sürdürülebilirliği ile ilgili kesin bir yorum yapmak mümkün değildir.

AlShahrani ve ark. ise erozyondan etkilenmiş dişlere zirkonyum destekli porselen materyali ile tam kuron restorasyonlar uygulamıştır. Bu tedavi seçeneğini tercih etme sebebi olarak kompozit reçine ve adeziv materyalin hastanın kusma atakları sırasındaki pH düşüşünden etkilenip çözünebileceğini ve bunun da restorasyonun ömrünü kısaltacağını düşündüğünü vurgulamıştır[51]. AlShahrani ve ark.'nın

42 I P a g e

www.iiste.org 
da beyan ettiği gibi adeziv bağlantı ile gerçekleştirdiğimiz reçine kompozit uygulamaları, tekrarlayan asit atakları sırasındaki $\mathrm{pH}$ değişikliklerinden etkilenip çözünmüş ve restorasyonların ömürleri kısalmıştır. Bu gerekçeye bağlı olarak zor olacağı düşünülen hastalarda, tedavinin kompozit reçine yerine asit ataklarından daha az etkilenmesi beklenen porselen materyaller ile tamamlanması tedavi seçenekleri arasında değerlendirilmelidir.

\section{Sonuç}

Yeme bozuklukları; psikolojik hastalıklar içinde ölümcül sonuçlara yol açma ihtimaliyle oldukça dikkat çeken ve daha sıklıkla genç kadınları etkileyen hastalıklardır. Yeme alışkanlıklarındaki değişikliklerin özellikle belli bir yaşın üzerinde görülmesi, geçmeyen kusma nöbetleri, hastanın kilosunda kısa süre içerisinde gözlenen değişimler tıbbi bir sorunun varlığından şüphe oluşturmaktadır. Kısa süre içerisinde meydana gelen kilo kaybını açıklayacak tıbbi bir problemin varlığı muhakkak araştırılmalıdır. Yeme bozuklukları anoreksiya nervoza teşhisi ile başlayıp ileride bulimia nervozaya dönüşebilir. Hastalık, dental erozyona sebep olabilir ve diş sert dokularında meydana gelen sert doku kaybı sonucu dişlerde hassasiyet problemlerine yol açabilir.

$\mathrm{Bu}$ vakada,18 yıldır kusmanın eşlik ettiği yeme bozukluğu olan 28 yaşındaki kadın hastanın durumu güncel literatür bilgileri ıșığında değerlendirilmiştir. Olgumuz; eroziv çürüksüz lezyonların tedavisinde, doğru bir endikasyon ile uygulanması ve gereken hasta motivasyonunun sağlanması şartıyla,direkt adeziv restorasyon uygulamalarının hastaya kaybolan estetik, fonksiyon ve fonasyonun tekrar kazandırılmasında konservatif tedavi seçenekleri arasındaki en uygun seçeneklerden biri olduğunu göstermiştir. Ayrıca yeme bozukluğu bulunan hastalarda uygulanan dental tedavinin başarısının hastalığın seyri ile doğrudan ilgili olduğunu, bu sebeple hastanın medikal ve dental olarak takibinin yapılmasının son derece önemli olduğu vurgulanmıştır.

Bu vaka çalışmaya katılan tüm yazarlar tarafindan okunmuştur ve onaylanmıştır. Dolayısılyla herhangi bir yazar, kurum ya da kuruluş ile çıkar çatışması olmadı̆̆ını belirtmek isteriz.

\section{Kaynakça}

[1] American Psychiatric Association. (2013), Diagnostic and Statistical Manual of Mental Disorders. 5 ed. Arlington, VA American Psychiatric Publishing.

[2] Vandereycken W., Lowenkopf EL. (1990), Anorexia nervosa in 19th century America. J Nerv Ment Dis 178(8):531-5.

[3] World Health Organization. (2015), The ICD-10 Classification of Mental and Behavioural Disorders. Clinical descriptions and diagnostic guidelines.

[4] Steinhausen, HC. (2020), Eating Disorders in Adolescence: Anorexia and Bulimia Nervosa. 3ed Berlin, Boston: De Gruyter.

[5] Zafersoy Z., Kayaoğlu G., Erten Can H., Üçtaşlı M. (2002) Çürük İçeren ve Çürük İçermeyen Servikal Lezyonların Etiyolojilerinin Klinik Olarak Değerlendirilmesi. Türkiye Klinikleri J Dental Sci 8:86-91.

[6] Friedman SB., Fisher MM., Schonberg SK., Alderman EM. (1998), Comprehensive Adolescent Health Care 2 ed. St Louis; Mosby: p. 247-262.

[7] Wang X., Lussi A. Assessment and management of dental erosion. (2010), Dent Clin North Am 54:565-78.

[8] Atila E., Eden E. (2011), Dental Erozyon: Etiyoloji, Tanı ve Tedavi Yaklaşımı. EÜ Dişhek Fak Derg 33:56-63.

43 I P a g e

www.iiste.org 
[9] El Aidi H., Bronkhorst EM., Huysmans MCDNJM, Truin GJ. (2010), Dynamics of tooth erosion in adolescents: a 3-year longitudinal study. J Dent 38:131-7.

[10] Järvinen VK., Rytömaa II., Heinonen O P. (1991), Risk factors in dental erosion. J Dent Res 70:942-7.

[11] Hasan S., Ahmed S., Panigrahi R., Chaudhary P., Vyas V., Saeed S. (2020), Oral cavity and eating disorders: An insight to holistic health. J Family Med Prim Care 9:3890-7.

[12] Little JW. Eating disorders: dental implications. (2002), Oral Surg Oral Med Oral Pathol Oral Radiol Endod 93:138-43.

[13] Liu XX., Tenenbaum HC., Wilder RS., Quock R., Hewlett ER, Ren YF. (2020), Pathogenesis, diagnosis and management of dentin hypersensitivity: an evidence-based overview for dental practitioners. BMC Oral Health 20:220.

[14] Ladalardo TCCGP., Pinheiro A., Campos RAC., Júnior AB., Zanin F., Albernaz PLM., Weckx LLM. (2004), Laser therapy in the treatment of dentine hypersensitivity. Braz Dent J 15:144-50.

[15] 15.Marsilio AL., Rodrigues JR., Borges AB. (2003), Effect of the clinical application of the GaAlAs laser in the treatment of dentine hypersensitivity. J Clin Laser Med Surg 21:291-6.

[16] Kimura Y., Wilder-Smith P., Yonaga K., Matsumoto K. (2000), Treatment of dentine hypersensitivity by lasers: a review. J Clin Periodontol 27:715-21.

[17] Birang R., Poursamimi J., Gutknecht N., Lampert F., Mir M. (2007), Comparative evaluation of the effects of Nd:YAG and Er:YAG laser in dentin hypersensitivity treatment. Lasers Med Sci 22:21-4.

[18] Aranha ACC, Eduardo CdeP, Cordas TA. (2008), Eating disorders part II: clinical strategies for dental treatment. J Contemp Dent Pract 9:89-96.

[19] Leach SA., Lee GT., Edgar WM. (1989), Remineralization of artificial caries-like lesions in human enamel in situ by chewing sorbitol gum. J Dent Res 68:1064-8.

[20] Kamak H., Alkan F., Okay TC., Erten H. (2013), Çeşitli İçeceklere Maruz Bırakılan Kompozit Rezinlerin Ağartıcı Diş Macunu İle Fırçalandıktan Sonra Mikropürüzlülüğünün Değerlendirilmesi. Atatürk Üniv Diş Hek Fak Derg 3:331-6.

[21] 21.Körner P., Wiedemeier DB., Attin T., Wegehaupt FJ. (2020), Prevention of Enamel Softening by Rinsing with a Calcium Solution before Dental Erosion. Caries Res 54:127-33.

[22] Milosevic A, Brodie DA, Slade PD. (1997), Dental erosion, oral hygiene, and nutrition in eating disorders. Int J Eat Disord 21:195-9.

[23] Hilsen KL. (2006), Treating dental patients with eating disorders. Dent Today 25:106-7.

[24] Hayashi M., Shimizu K., Takeshige F., Ebisu S. (2007), Restoration of erosion associated with gastroesophageal reflux caused by anorexia nervosa using ceramic laminate veneers: a case report. Operative dentistry 32:306-10.

[25] Kavoura V., Kourtis SG., Zoidis P., Andritsakis DP., Doukoudakis A. (2005), Full-mouth rehabilitation of a patient with bulimia nervosa. A case report. Quintessence Int 36:501-10. 
[26] Schuyler CH. (1963), The function and importance of incisal guidance in oral rehabilitation. The Journal of Prosthetic Dentistry 13:1011-29.

[27] Fairburn CG., Brownell KD. (2005), Eating disorders and obesity: A comprehensive handbook. 2 ed. Newyork; Guilford Press.

[28] Öztürk MO., Uluşahin A. (2004), Ruh Sağlığı ve Bozuklukları. 16 ed. İstanbul; Nobel Tip Kitabevleri: .p.471-89

[29] Bäckman B., Holm AK. (1986), Amelogenesis imperfecta: prevalence and incidence in a northern Swedish county. Community Dent Oral Epidemiol 14:43-7.

[30] Yüzügüllü B., Tezcan S. (2005), Renk değişimine ve mine erozyona uğramış dişlerde laminat veneer restorasyon seçeneklerin endikasyon bakımından karşılaştırılması. CÜ Dişhek. Fak Der 8:133-7.

[31] Zorba YO., Ercan E. (2008), Direkt uygulanan kompozit laminate veneerlerin klinik değerlendirilmeleri: iki olgu sunumu. SÜ Diş hek Fak Der 17:130-5.

[32] Bağış B., Bağış HY. (2006), Porselen laminate veneerlerin klinik Uygulama aşamaları: Klinik bir olgu sunumu AÜ Dişhek Fak Der 33:49-57.

[33] Hickel R., Heidemann D., Staehle HJ., Minnig P., Wilson NHF. (2004), Direct composite restorations extended use in anterior and posterior situations. Clin Oral Invest 8:43-4.

[34] Türkün LS. (2005), Conservative restoration with resin composites of a case of amelogenesis imperfecta. Int Dent J 55:38-41..

[35] Pontons-Melo JC., Atzeri G., Collares FM., Hirata R. (2019), Cosmetic recontouring for achieving anterior esthetics. Int J Esthet Dent 14:134-46.

[36] Devoto W., Pansecchi D. (2007), Composite restorations in the anterior region: clinical and aesthetic performances. Pract Proced Aesthet Dent 19:465-70.

[37] Kanzow P., Wiegand A., Göstemeyer G., Schwendicke F. (2018), Understanding the management and teaching of dental restoration repair: Systematic review and meta-analysis of surveys. J Dent 69:1-21.

[38] Yazıcıŏglu O. (2016), Treatment approach for restoring the peg-shaped incisors. AÜ Dişhek Fak Der. 26:1-11.

[39] Yazıcıŏlu O., Ulukapı H. (2014), Management of a facial talon cusp on a maxillary permanent central incisor: a case report and review of the literature. J Esthet Restor Dent 26:374-81.

[40] DeBate RD., Tedesco LA., Kerschbaum WE. (2005), Knowledge of oral and physical manifestations of anorexia and bulimia nervosa among dentists and dental hygienists. Journal of dental education 69:346-54.

[41] Dublin Dental University Hospital, The Irish Dental Association. (2018), Eating Disorders A Resource for Dentists. Dublin;Think Bodywhys CLG.

[42] Küey G. (2008), Çocuk ve Ergen Psikyatrisi Temel Kitabı. Ankara; Çocuk ve Gençlik Ruh Sağlığı Yayınları. 
[43] Rangé H., Pallier A., Ali A, Huas C., Colon P., Godart N. (2021), Risk Factors for Oral Health in Anorexia Nervosa: Comparison of a Self-Report Questionnaire and a Face-to-Face Interview. Int J Environ Res Public Health 18:4212.

[44] Borcic J., Anic I., Urek MM., Ferreri S. (2004), The prevalence of non-carious cervical lesions in permanent dentition. J Oral Rehabil 31:117-23.

[45] Moazzez R., Bartlett D., Anggiansah A. (2004), Dental erosion, gastro-eosophageal reflux disease and saliva: how are they related? Journal of dentistry 32:489-94.

[46] de Moor RJ. (2004), Eating disorder-induced dental complications: a case report. J Oral Rehabil 31:725-32.

[47] Hemmings KW., Darbar UR., Vaughan S. (2000), Tooth wear treated with direct composite restorations at an increased vertical dimension: results at 30 months. J Prosthet Dent 83:287-93.

[48] Poyser NJ., Briggs PFA., Chana HS., Kelleher MGD., Porter RWJ., Patel MM. (2007), The evaluation of direct composite restorations for the worn mandibular anterior dentition-clinical performance and patient satisfaction. Journal of oral rehabilitation J Oral Rehabil 34:361-76.

[49] Kaur S., Makkar S., Kumar R., Pasricha S., Gupta P. (2015), Comparative evaluation of surface properties of enamel and different esthetic restorative materials under erosive and abrasive challenges: An in vitro study. Indian J Dent 6:172-80.

[50] Harrison's Principles of Internal Medicine. (2016), Anorexia nervosa and bulimia nervosa. 19 ed. New York; McGraw-Hill Book: p. 462-72.

[51] AlShahrani MT., Haralur SB., Alqarni M. (2017), Restorative Rehabilitation of a Patient with Dental Erosion. Case Rep Dent 9517486. 